\title{
REASONS WHY PATIENTS REJECT DIGITAL RECTAL EXAMINATION WHEN SCREENING FOR PROSTATE CANCER
}

\author{
Frederico R. Romero 1,3, Karen Richter P. Santos Romero², Thadeu Brenny Filho3, Roberto Pilati3, \\ David Kulysz and Fernando César de Oliveira Júnior?.
}

Instituto Curitiba de Saúdel (ICS), Ministério Público do Estado do Paraná2, and Hospital São Vicente de Curitiba ${ }^{3}$ Curitiba. PR. Brazil.

\begin{abstract}
Summary.- OBJECTIVE: To evaluate the reasons why patients reject digital rectal examination (DRE) when screening for prostate cancer.

METHODS: Four hundred and fifty men were prospectively evaluated in a prostate cancer educational program consisting of lectures, PSA testing, and DRE. Patients rejecting DRE were compared with those accepting DRE in regard to epidemic, social and cultural variables.

RESULTS: DRE was rejected by $8.2 \%$ of patients. Refusal rate was not different when patients were stratified by age, prostate cancer family history, school level, family income, and PSA level. Patients with a prior history of DRE had a lower rejection rate than those undergoing DRE for the first time $14.4 \%$ vs. $10.4 \%, p=0.038)$. Patients with mild or no lower urinary tract symptoms rejected DRE more frequently than those with moderate or
\end{abstract}

Frederico Ramalho Romero Rua Emiliano Perneta, 653 ap 41 80420-080 Curitiba. PR. (Brazil). frederico.romero@gmail.com Accepted for publication: 9th August, 2007. severe symptoms $19.6 \%$ vs. $1.4 \%, p=0.018)$. Misconceptions about prostate cancer screening were present in $84.4 \%$ of those rejecting DRE vs. $46.9 \%$ of controls ( $p=0.002) ; 43.7 \%$ expected severe discomfort in the group that rejected DRE vs. $28.1 \%$ in the control group ( $p=0.090)$; fear of finding a cancer during DRE was present in $34.4 \%$ of patients that refused DRE vs. $46.9 \%$ of controls ( $p=0.121)$; and $53.1 \%$ of patients rejecting DRE responded it was a source of shame vs. $15.6 \%$ of patients in the control group ( $p=0.019)$.

CONCLUSIONS: The main reasons patients reject DRE when attending prostate cancer screening are the lack of lower urinary tract symptoms, misconceptions about prostate cancer screening and shame, especially when undergoing screening for the first time.

Keywords: Prostate cancer; Screening. Refusal. Questionnaire. Shame. Anxiety. Belief.

Resumen.- OBJETIVO: Evaluar las razones por las que los pacientes rechazan el tacto rectal cuando se someten a cribaje de cáncer de próstata.

MÉTODOS: 450 hombres fueron evaluados respectivamente en un programa de educación sobre cáncer de próstata consistente en conferencias, evaluación del PSA y tacto rectal. Se compararon los pacientes que rechazaron el tacto rectal con los que aceptaron hacérselo considerando las variables epidemiológicas, sociales y culturales.

RESULTADOS: El 8,2\% de los pacientes rechazaron el tacto rectal. La tasa de rechazos no mostró diferencias cuando se estratifica los pacientes por edad, historia familiar de cáncer de próstata, nivel de escolarización, ingresos familiares y nivel del PSA. Los pacientes con historia previa de tacto rectal presentaron una tasa de 
rechazo menor que aquellos sometidos a tacto rectal por primera vez $(4,4 \%$ vs. $10,4 \%, p=0,038)$. Los pacientes asintomáticos o con síntomas del tracto urinario inferior leves rechazaron el tacto rectal con mayor frecuencia que los que tenían síntomas moderados o severos $(9,6 \%$ vs. $1,4 \%, p=0,018)$. El $84 \%$ de los que rechazaron el tacto rectal tenían un concepto erróneo sobre el cribaje cáncer de próstata frente al 46,9\% de los controles ( $p=0,002$ ); en 43,7\% del grupo que rechazaron el tacto rectal esperaban una molestia severa frente al 28, $1 \%$ del grupo control $(p=0,090)$; el miedo a que le fuera detectado cáncer durante el tacto rectal está presente del $34,4 \%$ de los pacientes que rechazaron el tacto rectal frente al $46,9 \%$ de los controles $(p=$ 0,1211 ; y el 53,1\% de los pacientes que rechazaron el tacto rectal respondieron que este era una motivo de vergüenza, frente al 15,6\% de los pacientes del grupo control $(p=0,019)$.

CONCLUSIONES: Las principales razones por las que los pacientes rechazan el tacto rectal cuando se someten a cribaje de cáncer de próstata son la falta de síntomas del tracto urinario inferior, conceptos erróneos sobre el cribaje de cáncer de próstata y la vergüenza, especialmente cuando se someten a cribaje por primera vez.

Palabras clave: Cáncer de próstata. Cribaje. Rechazo. Cuestionario. Vergüenza. Ansiedad. Creencias.

\section{INTRODUCTION}

Prostate cancer is the most common form of noncutaneous cancer in men and the second leading cause of male cancer mortality. In the United States, it is estimated that 218,890 new cases and 27,050 deaths from prostate cancer will occur in 2007 (1).

Digital rectal exam (DRE) is an important tool and should be used routinely during prostate cancer screening. Although measurement of the serum tumor marker prostate-specific antigen (PSA) has the highest positive predictive value for prostate cancer, use of PSA without DRE is not recommended because 25\% of men with prostate cancer have PSA levels less than $4 \mathrm{ng} / \mathrm{mL}$. (2) American Urological Association (AUA) and American Cancer Society (ACS) recommend that both DRE and PSA measurement should be offered annualy, beginning at age 50 .

Despite this widespread concept, recent studies showed that $38 \%$ of patients screened for prostate cancer stated their physicians did not recommend DRE (3), and $53 \%$ of men who underwent PSA testing did not have a DRE performed (4). Several reasons may account for these low numbers including medical misconceptions and patients' expectations and fears $(4,5)$.
To help in patients' and physicians' education we performed a study to evaluate why men refuse to undergo DRE when screening for prostate cancer.

\section{MATERIAL AND METHODS}

\section{Patient Selection}

During a prostate cancer educational program with a series of lectures in our Institution, 450 consecutive volunteers aged 40 years or older underwent a free prostate cancer screening consisting of serum PSA measurement followed by physician consultation. At consultation patients answered the international prostate symptom score (IPSS) and a general questionnaire including age, prior history of DRE for prostate cancer screening, prostate cancer family history, school level education, and monthly family income. All patients were then offered DRE.

Patients initially refusing DRE were oriented once more about the importance of the examination regardless of PSA values, that both DRE and PSA are complementary, and that $25 \%$ of men with prostate cancer have PSA levels less than $4.0 \mathrm{ng} / \mathrm{mL}$. They were however reassured that if they felt more comfortable they could undergo DRE in the future.

Patients who eventually refused DRE as part of the screening process were compared with those who accepted DRE in regard to age, prior history of DRE, prostate cancer family history, school level, monthly family income, IPSS, and serum PSA level. Patients refusing DRE were also asked to respond a self-administered questionnaire regarding prostate cancer education and patients' expectations. For each patient that refused DRE, a patient that accepted it - matched by age, prior history of DRE, prostate cancer family history, school level and income, IPSS, and PSA level - was asked to answer the same questionnaire immediately before DRE as a control measure for comparison (control group).

\section{Questionnaire}

After informed consent was obtained, patients responded a self-administered anonymous questionnaire containing 5 questions (Table I). The first two questions regard patients' education about prostate cancer screening. The following two questions evaluate patients' expectations regarding anticipation of discomfort, and fear of finding a cancer. The final question asks if the patients believe that the prostate exam is a reason for shame.

\section{Statistical analysis}

Patients were empirically stratified by age (younger than 50 years vs. equal to or older than 50 
years), prior history of DRE for prostate cancer screening (yes vs. no), prostate cancer family history (yes vs. no), school level education (illiterate or incomplete elementary school vs. complete elementary school or higher), monthly family income (5 times the national minimum salary or less vs. more than 5 minimum salaries), and PSA level (equal to or less than $4.0 \mathrm{ng} / \mathrm{mL}$ vs. $4.1 \mathrm{ng} / \mathrm{mL}$ or higher).

Resuts from the questionnaire were grouped as categorical variables. The two questions regarding patient education had three possible answers with only one correct answer each. Patients were grouped as they gave a correct vs. incorrect answer to each question. Answers regarding discomfort anticipation were grouped as "no discomfort" or "yes, mild discomfort" vs. "yes, severe discomfort". Answers re- garding fear of finding a cancer and those arguing wether or not prostate exam was a reason for shame were grouped as "yes" vs. "no".

Statistical analysis was performed using twosided Fisher's exact test or Pearson's chi-square test, whichever was appropriate. Statistical significant values were considered when $p<0.05$.

\section{RESULTS}

Of a total 450 consecutive patients, 37 $(8.2 \%)$ refused DRE as part of the screening program. Table II lists demographics of patients rejecting DRE compared with those of patients accepting DRE. Median age was 51 years (range 40 - 69) for those

\section{TABLE I. QUESTIONNAIRE.}

1. Which of the following is the best method for detecting prostate cancer?

1. PSA alone

2. Prostate exam alone

3. PSA + Prostate exam *

\section{Which of the following group of patients should undergo a prostate exam?}

1. All patients performing PSA *

2. Patients with symptoms

3. Patients with abnormal PSA levels

\section{How much discomfort/pain do you expect to have during the prostate exam?}

1. No discomfort

2. Mild discomfort

3. Severe discomfort

4. Do you fear the prostate exam might find a prostate cancer in you?

1. Yes

2. No

\section{Do you believe the prostate exam is a reason for shame?}

1. Yes

2. No 
who accepted DRE, and 52 years (range 40 - 66) for those who rejected it. 308 (69.4\%) patients had prior history of DRE for prostate cancer screening, while $136(30.6 \%)$ were undergoing prostate cancer screening for the first time. Prostate cancer family history was present in 21 (4.7\%) patients. 147 (32.7\%) pa- tients had incomplete elementary school education, and $303(67.3 \%)$ patients had a complete elementary school or higher education. Median IPSS was $3 \pm$ 5 for the group of patients that accepted DRE against $1 \pm 2$ in the group that rejected DRE. Overall, 74 (16.5\%) patients had IPSS equal to or greater than

TABLE II. SOCIAL AND EPIDEMIC VARIABLES.

\begin{tabular}{|c|c|c|c|}
\hline & $\begin{array}{l}\text { Accept } \\
\text { No. (\%) }\end{array}$ & $\begin{array}{c}\text { Reject } \\
\text { No. (\%) }\end{array}$ & p Value \\
\hline $\begin{array}{l}<50 \text { years } \\
\geq 50 \text { years }\end{array}$ & $\begin{array}{l}162(91.0) \\
248(92.2)\end{array}$ & $\begin{array}{l}16(9.0) \\
21(7.8)\end{array}$ & 0.657 \\
\hline $\begin{array}{c}\text { Prior history of DRE } \\
\text { No } \\
\text { Yes }\end{array}$ & $\begin{array}{l}276(89.6) \\
130(95.6)\end{array}$ & $\begin{array}{c}32(10.4) \\
6(4.4)\end{array}$ & 0.038 \\
\hline $\begin{array}{l}\text { Prostate cancer family history } \\
\qquad \begin{array}{c}\text { No } \\
\text { Yes }\end{array}\end{array}$ & $\begin{array}{c}392(91.6) \\
19(90.5)\end{array}$ & $\begin{array}{c}36(8.4) \\
2(9.5)\end{array}$ & 0.858 \\
\hline $\begin{array}{l}\text { School level } \\
\text { Incomplete } \\
\text { elementary school } \\
\text { Complete } \\
\text { elementeray school of higher }\end{array}$ & $\begin{array}{l}133(90.5) \\
279(92.1)\end{array}$ & $\begin{array}{l}14(9.5) \\
24(7.9)\end{array}$ & 0.566 \\
\hline $\begin{array}{l}\text { Monthly family income } \\
\qquad \begin{array}{l}<\text { minimum salaries } \\
\quad \geq 5 \text { minimum salaries }\end{array}\end{array}$ & $\begin{array}{l}261(91.3) \\
149(92.0)\end{array}$ & $\begin{array}{l}25(8.7) \\
13(8.0)\end{array}$ & 0.794 \\
\hline $\begin{array}{l}<8 \\
\geq 8 \\
\end{array}$ & $\begin{array}{c}339(90.4) \\
73(98.6) \\
\end{array}$ & $\begin{array}{c}36(9.6) \\
1(1.4) \\
\end{array}$ & 0.018 \\
\hline $\begin{array}{l}\text { PSA level } \\
\qquad \begin{aligned}<4.0 \mathrm{ng} / \mathrm{mL} \\
\geq 4.0 \mathrm{ng} / \mathrm{mL}\end{aligned}\end{array}$ & $\begin{array}{c}393(91.4) \\
14(93.3)\end{array}$ & $\begin{array}{c}37(8.6) \\
1(6.7)\end{array}$ & 0.792 \\
\hline
\end{tabular}


8. Median PSA level was $0.78 \pm 1.23 \mathrm{ng} / \mathrm{mL}$ in the group that accepted DRE and $1.02 \pm 0.89 \mathrm{ng} / \mathrm{mL}$ in the group that rejected it. Fifteen $(3.4 \%)$ patients presented with a PSA level greater than $4.0 \mathrm{ng} / \mathrm{mL}$.

Of 37 patients refusing DRE, 32 (86.5\%) patients answered the questionnaire. Five patients could not respond the questionnaire because they were illiterate. Thirty-two matched patients that accepted DRE also answered the questionnaire as a control measure for comparison.

Regarding patient education about prostate cancer screening, thirteen $(40.6 \%)$ patients rejecting DRE answered PSA alone was the best method for detecting prostate cancer compared to only one $(3.1 \%)$ patient in the control group $(p<0.001)$; eight $(25 \%)$ patients rejecting DRE believed only patients with symptoms should receive DRE when screening for prostate cancer against two $(6.2 \%)$ patients in the control group ( $p=0.034)$; and $17(53.1 \%)$ patients rejecting DRE responded only patients with abnormal PSA levels should receive DRE compared to eight $(25 \%)$ patients in the acceptance group $(p=0.014)$.

Concerning discomfort anticipation, 14 $(43.7 \%)$ and nine $(28.1 \%)$ patients expected severe discomfort during DRE in the group of patients that rejected DRE and in the control group respectively ( $p$ $=0.090$ ). Fear of finding a cancer during DRE was present in $11(34.4 \%)$ patients that refused DRE and in $15(46.9 \%)$ of controls $(p=0.121)$. DRE was a reason for shame for $17(53.1 \%)$ patients that refused DRE, and in five $(15.6 \%)$ of the patients that accepted $\operatorname{DRE}(p=0.019)$.

\section{DISCUSSION}

Screening for prostate cancer is controversial (4). To our knowledge, solid evidence that screening for prostate cancer reduces morbidity or mortality has not yet been shown. However, several indirect evidence support that early detection may be beneficial. Men who undergo PSA screening are more likely to have early-stage disease at diagnosis, and the proportion of cancers that are clinically or pathologically advanced appears to decrease with each successive year of testing. Declines in prostate cancer mortality since 1991 give additional evidence for prostate cancer screening.

Although this controversy remains, AUA and ACS recommend that prostate cancer screening should be offered annually beginning at age 50 to men who have at least a 10-year life expectancy. Men at high risk - African-American men and those with one or more first-degree relatives - should begin testing at age 45 .

Whenever prostate cancer screening is done, the importance of DRE can not be overemphasized and the implications of not performing DRE are many (4). Up to a quarter of men with prostate cancer have PSA levels less than $4 \mathrm{ng} / \mathrm{mL}$ that would have been missed if DRE was neglected (2).

Misconceptions about prostate cancer screening are important barriers to DRE $(6,7)$. A significant number of patients rejecting DRE in the present study answered that PSA measurement alone was the most important procedure - instead of the combination of serum PSA and DRE - to detect prostate cancer, and that only patients with symptoms or those with an abnormal PSA should undergo DRE when screening for prostate cancer.

Since physicians are responsible for most information patients and other health care providers share (8), we have to assume our part of responsibility for these misconceptions. Physician recommendations have been previously reported to predict screening behavior (7-9). Because of the perception that PSA testing is superior, some physicians believe and advise their patients that DRE adds no further to PSA testing in prostate cancer screening especially if PSA is very low. Patients may reject DRE based on this information. DRE is in fact most important in patients with a "normal" PSA level because individuals with an elevated PSA level receive, presumably, further examination (4). Patients with PSA lower than 4.0 $\mathrm{ng} / \mathrm{mL}$ should always be advised that DRE may provide additional information that may be overlooked by the low PSA level.

Previous studies reported that absence of urological complaints was one of the main motives for patients refusing prostate cancer screening $(5,10)$. Supporting this information, we found that only $1.4 \%$ of patients rejected DRE if they had a moderate or higher lower urinary tract symptoms defined by an IPSS equal to or greater than 8 , compared to $9.6 \%$ of patients with mild or no symptoms (IPSS $\leq 7, p=$ $0.018)$. Patient education should stress that men can have prostate cancer and still have no symptoms, feel well, and seem normal to others (9).

Social and cultural beliefs may also play a role in patients' refusal to DRE. Nearly half of patients rejecting DRE in our study reported they believe DRE is a reason for shame. It has been reported that cultural beliefs about masculinity may create barriers to help care seeking (1) that are clearly stressed when "invasive" procedures such as DRE are expected. Although 
they rationally understand that DRE is an important exam, some men may find that undergoing DRE is not an acceptable behavior for men. Cultural myths correlate DRE to a sexual experience or homosexuality. Imagined or real fears toward sexual function (e.g., false beliefs that DRE may cause impotence and real concerns about prostate cancer treatment complications such as impotence and urinary incontinence) may also affect significantly a man's beliefs about his masculinity or about his ability to satisfy his own and his partner's sexual desires (11).

Despite these influences on masculinity, roles are not necessarily fixed and may be open for changes (11). Redefining conceptions about prostate cancer - and screening - in a way that reaffirms rather than threatens masculine identity may help some men to maintain part of the masculine coping process (12). This suggests a role for educational programs which encourage changing behaviors that result from adherence to masculine ideologies and making health support more acceptable for men (11). Educational programs through seminars, and information provided by electronic and print media are established to decrease patients' misconceptions and to increase patient intention to undergo prostate cancer screening $(6,8)$. Patients should be clarified that although DRE may bring up gender-related anxieties and resistan$c e$, it is a rapid procedure as important as serum PSA that is performed through the rectum only because of its proximity to the prostate.

Prior prostate cancer screening program has been previously reported as an important predictor of participation in future screening (8). Our study shows that patients with prior history of DRE have a lower DRE refusal rate than patients undergoing prostate cancer screening for the first time. This demonstrates that patients' expectations and anxieties may be surpassed after the first examination. Breaking this firsttime barrier should increase participation in prostate cancer screening.

Lower age $(8,14)$, no family history for prostate cancer $(8,14)$, anticipated pain and discomfort $(5,10)$, and low school level and family income (8$10,15)$ were previously reported as barriers to DRE and prostate cancer screening. These factors were not associated with a different DRE refusal rate in our study. Other barriers to prostate cancer screening reported in the literature that were not evaluated in this study include screening costs (8), and patients' race and marital status $(7,8,15)$.

The extent to which findings from the study may be generalized may be limited because participating men were patients in an established health care system enrolled in a free prostate cancer educational program. This study however provides important insights about potential reasons patients may refuse DRE, which should be addressed during population-based prostate cancer screening programs.

\section{CONCLUSIONS}

When screening for prostate cancer, patients may reject DRE because of the lack of lower urinary tract symptoms, misconceptions about prostate cancer screening, and because they believe DRE is a reason for shame. Rejection rate is greater for patients undergoing prostate cancer screening for the first time.

\section{REFERENCES AND RECOMENDED READINGS (*of special interest, ${ }^{* *}$ of outstanding interest)}

1. JEMAL, A.; SIEGEL, R.; WARD, E. y cols.: "Cancer Statistics, 2007”. C.A. Cancer J. Clin., 57: 43, 2007.

*2. CARTER, H.B.; PARTIN, A.W.: "Diagnosis and staging of prostate cancer". in Walsh, P.C.; Retik, A.B.; Vaughan Jr, E.D.; and Wein, A.J. (eds): Campbell's Urology, vol 4, pp 3055 - 3079, WB Saunders Co., Philadelphia, 2002.

3. STEELE, C.B.; MILLHER, D.S.; MAYLAHN, C. y cols.: "Knowledge, attitudes, and screening practices among older men regarding prostate cancer". Am. J. Public Health, 90: 1595, 2000.

**4. MURTHY, G.D.; BYRON, D.P.; PASQUALE, D. y cols.: "Underutilization of digital rectal examination when screening for prostate cancer." Arch. Intern. Med., 164: 313, 2004.

**5. NIJS, H.G.; ESSINK-BOT, M.L.; DEKONING, H.J. y cols.: "Why do men refuse or attend population-based screening for prostate cancer?" J. Public Health Med., 22: 312, 2000.

*6. WILKINSON, S.; LIST, M.; SINNER, M. y cols.: "Educating african-american men about prostate cancer: impact on awareness and knowledge". Urology, 61: 308, 2003.

**7. DEMARK-WAHNEFRIED, W.; STRIGO, T.; CATOE, K. y cols.: "Knowledge, belifs and prior screening behavior among blacks and whites reporting for prostate cancer screening". Urology, 46: 346, 1995.

**8. NIVENS, A.S.; HERMAN, J.; WEINRICH, S.P. y cols.: "Cues to participation in prostate cancer screening: a theory for practice". Oncol. Nurs. Forum, 28: 1449, 2001. 
*9. MYERS, R.E.; HYSLOP, T.; WOLF, T.A. y cols.: "African-american men and intention to adhere to recommended follow-up for an abnormal prostate cancer early detection examination result". Urology, 55: 716, 2000.

**10. LUCUMI-CUESTA, D.I.; CABREARA-ARANA, G.A.: "Beliefs of men from Cali, Colombia, about digital rectal examination: Findings of an exploratory study". Cad. Saude Publica, 21: 1491, 2005.

11. WALKER, S.: "Prostate cancer support groups: an evaluation". Department of Psychology. Swinburne University of Technology, Melbourne, Australia, 2005. http://adt.lib.swin.edu.au/uploads/approved/ adt-VSWT20060905.085536/public/01front.pdf

12. GRAY, R.E.; FITCH, M.L.; FERGUS, K.D. y cols.: "Hegemonic masculinity and the experience of prostate cancer: a narrative approach". J. Aging Ident., 7: 43, 2002.

13. GRAY, R.E.; FITCH, M.; DAVIS, C. y cols.: "Interviews with men with prostate cancer about their self help group experience". J. Palliat. Care, 13: 15, 1997.

*14. MILLER, S.M.; DIEFENBACH, M.A.; KRUUS, L.K. y cols.: "Psychological and screening profiles of first-degree relatives of prostate cancer patients". J. Behav. Med., 24: 247, 2001.

*15. WEINRICH, S.P.; WEINRICH, M.C.; PRIEST, J. y cols.: "Self-reported reasons men decide not to participate in free prostate cancer screening". Oncol. Nurs. Forum, 30: 2, 2003. 